\title{
How Inflammation Pathways Contribute to Cell Death in Neuro-Muscular Disorders
}

\author{
Sara Salucci ${ }^{1,2, * \mathbb{D}}$, Anna Bartoletti Stella ${ }^{3}$, Michela Battistelli ${ }^{1}$, Sabrina Burattini ${ }^{1}$, Alberto Bavelloni ${ }^{4} \mathbb{D}$, \\ Lucio Ildebrando Cocco ${ }^{2}(\mathbb{D})$, Pietro Gobbi ${ }^{1,+}+\mathbb{D}$ and Irene Faenza ${ }^{2,+}$ \\ 1 Department of Biomolecular Sciences (DiSB), Urbino University Carlo Bo, 61029 Urbino, Italy; \\ michela.battistelli@uniurb.it (M.B.); sabrina.burattini@uniurb.it (S.B.); pietro.gobbi@uniurb.it (P.G.) \\ 2 Cellular Signalling Laboratory, Department of Biomedical and NeuroMotor Sciences (DIBINEM), \\ University of Bologna, 40126 Bologna, Italy; lucio.cocco@unibo.it (L.I.C.); irene.faenza2@unibo.it (I.F.) \\ 3 Department of Diagnostic Experimental and Specialty Medicine (DIMES), University of Bologna, \\ 40126 Bologna, Italy; anna.bartoletti2@unibo.it \\ 4 Laboratory of Experimental Oncology, IRCCS Istituto Ortopedico Rizzoli, 40136 Bologna, Italy; \\ alberto.bavelloni@ior.it \\ * Correspondence: sara.salucci@uniurb.it \\ + Equally contributed.
}

\section{check for}

updates

Citation: Salucci, S.;

Bartoletti Stella, A.; Battistelli, M.;

Burattini, S.; Bavelloni, A.; Cocco, L.I.;

Gobbi, P.; Faenza, I. How

Inflammation Pathways Contribute to

Cell Death in Neuro-Muscular

Disorders. Biomolecules 2021, 11, 1109.

https: / /doi.org/10.3390/biom

11081109

Academic Editor:

Vladimir N. Uversky

Received: 24 June 2021

Accepted: 26 July 2021

Published: 28 July 2021

Publisher's Note: MDPI stays neutral with regard to jurisdictional claims in published maps and institutional affiliations.

Copyright: (C) 2021 by the authors. Licensee MDPI, Basel, Switzerland. This article is an open access article distributed under the terms and conditions of the Creative Commons Attribution (CC BY) license (https:// creativecommons.org/licenses/by/ $4.0 /)$.

\begin{abstract}
Neuro-muscular disorders include a variety of diseases induced by genetic mutations resulting in muscle weakness and waste, swallowing and breathing difficulties. However, muscle alterations and nerve depletions involve specific molecular and cellular mechanisms which lead to the loss of motor-nerve or skeletal-muscle function, often due to an excessive cell death. Morphological and molecular studies demonstrated that a high number of these disorders seem characterized by an upregulated apoptosis which significantly contributes to the pathology. Cell death involvement is the consequence of some cellular processes that occur during diseases, including mitochondrial dysfunction, protein aggregation, free radical generation, excitotoxicity and inflammation. The latter represents an important mediator of disease progression, which, in the central nervous system, is known as neuroinflammation, characterized by reactive microglia and astroglia, as well the infiltration of peripheral monocytes and lymphocytes. Some of the mechanisms underlying inflammation have been linked to reactive oxygen species accumulation, which trigger mitochondrial genomic and respiratory chain instability, autophagy impairment and finally neuron or muscle cell death. This review discusses the main inflammatory pathways contributing to cell death in neuro-muscular disorders by highlighting the main mechanisms, the knowledge of which appears essential in developing therapeutic strategies to prevent the consequent neuron loss and muscle wasting.
\end{abstract}

Keywords: neuro-muscular diseases; motor neuron disorders; innate immune system; neuroinflammation; cell death

\section{Introduction}

Injury or dysfunctions of the motor neuron, the pheripheral nerve or muscles are correlated to a group of disorders known as neuro-muscular diseases [1-4], which include motoneuron disorders, diseases of the pheripheral nerve or of neuromuscular junction, and muscle disease such as muscular dystrophies [5-7] and myopathies (see Table 1 in which two main diseases for each class have been reported). The innate immune system represents the main defense against infection and is involved in tissue repair by eliminating apoptotic cells and cellular debris [8]. It is known that its excessive activation, as well as its non-resolving, induces an inflammatory response [9] which contributes to the disease's progression. This review is an update of the role of inflammation in inducing cell death in neuro-muscular disorders by highlighting the main inflammatory pathways and discussing their relationship with the innate immune system. In particular, the review focuses on the crucial role of inflammation correlated to cell death by deepening these 
aspects of motor neuron diseases. In these pathologies, a motor unit number reduction has been documented $[10,11]$, even if the molecular mediators which lead to inflammation and neuron cell death have been poorly characterized. In particular, two prominent motor neuron diseases, amyotrophic lateral sclerosis (ALS) and spinal muscular atrophy (SMA), have been discussed as highlighting the relationship between inflammation and neuron death.

Table 1. Classification of neuro-muscular diseases.

\begin{tabular}{ccccc}
\hline $\begin{array}{c}\text { Motor Neuron } \\
\text { Disorders }\end{array}$ & $\begin{array}{c}\text { Pheripheral Nerve } \\
\text { Diseases }\end{array}$ & $\begin{array}{c}\text { Neuro-Muscular } \\
\text { Junction Diseases }\end{array}$ & Muscular Dytrophies & Myopathies \\
\hline $\begin{array}{c}\text { Amiotrophic Lateral } \\
\text { Sclerosis (ALS) }\end{array}$ & $\begin{array}{c}\text { Charcot-Marie-Tooth } \\
\text { disease (CMT) }\end{array}$ & Myastenia Gravis (MG) & $\begin{array}{c}\text { Duchenne Muscular } \\
\text { Dystrophy (DMD) }\end{array}$ & $\begin{array}{c}\text { Inflammatory } \\
\text { Myopathies }\end{array}$ \\
\hline $\begin{array}{c}\text { Spinal muscle atrophy } \\
\text { (SMA) }\end{array}$ & $\begin{array}{c}\text { Giant Axonal } \\
\text { Neuropathy }\end{array}$ & $\begin{array}{c}\text { Congenital Myasthenic } \\
\text { Syndromes (CMS) }\end{array}$ & $\begin{array}{c}\text { Becker Muscular } \\
\text { Dystrophy (BMD) }\end{array}$ & Metabolic Myopathies \\
\hline
\end{tabular}

\section{Motor Neuron Disorders}

Among the neurodegenerative diseases characterized by impaired motoneuron function, are ALS and SMA, the patho-mechanisms of which are largely unknown [12-14]. ALS is a fatal neurodegenerative disease characterized by progressive muscle paralysis determined by the degeneration of upper motoneurons in the primary motor cortex, lower motoneurons in the brainstem and in the spinal cord [15]. Genetic susceptibility and environmental exposure contributes to the pathogenesis of ALS which can be sporadic or familial, although the distinction can be difficult to assign [16,17]. Neuron death is probably induced by the inability to manage protein aggregates, mitochondrial instability, excess of oxidative stress, defective axonal transport and glutamate toxicity $[18,19]$. The latter, also known as excitotoxicity, is characterized by glutamatergic overstimulation of motor neurons leading to neurodegeneration by excessive cytosolic calcium release which involves, at least in part, the activation of inositol 1,4,5-trisphosphate receptors located in the ER membrane [20,21]. ALS also involves abnormalities of metabolism and the immune system, including neuroinflammation in the brain and spinal cord [22,23]. Strikingly, abnormalities of the peripheral immune system, with alterations of $\mathrm{T}$ lymphocytes, monocytes, complement and cytokines, appear in the peripheral blood of ALS patients. Motoneuron degeneration leads to progressive muscle weakness and wasting, body weight loss, fasciculation, emotional lability and cognitive dysfunction. Around 50 genes have been identified as being involved in the course of ALS [24,25]. The most common cause of ALS is correlated to the repeat expansion of the intronichexanucleotides (G4C2) in the chromosome 9 open reading frame72 (C9orf72) region of the human chromosome 9 [26]. Furthermore, ALS is characterized by other mutations which most involve the SOD copper-zinc 1 (SOD1) gene [27] and, to a lesser extent, mutations in genes that code for TDP-43, fused in sarcoma (FUS) and others [24,25].

In particular, mutant SOD1 is neurotoxic through multiple mechanisms including protein aggregation, oxidative stress, mitochondrial dysfunction and excitotoxicity. Furthermore, it is pathogenic in familial ALS and, in some cases, in sporadic one. On the other hand, TDP43 and FUS are essential proteins involved in several RNA-processing events, including splicing, transcription and translation. Hyper-phosphorylated and ubiquitinated TDP-43 or FUS deposits lead to inclusion body accumulation in the brain and spinal cord of patients and consequent motor neuron degeneration. Although pathological pathways leading to ALS seem to differ between SOD1, TDP-43 and FUS cases, a common hallmark resides in toxic protein aggregation [24,25].

Spinal muscular atrophy (SMA) is a motor neuron degeneration, which occurs in the spinal cord causing progressive weaknesses in the limbs and trunk, followed by muscle atrophy [28]. SMA is an autosomal recessive disease characterized by a variable phenotype. The disease is classified in typeI-III based on age at the onset of the disease and clinical 
course. Mutations in the survival motor neuron gene (SMN1) on chromosome $5 q 13$ cause this disorder and induce the loss of motor neurons in the ventral horn of the spinal cord and the subsequent weakness and atrophy of skeletal muscles [29-31]. The homologous SMN2 gene, coding for the SMN protein, it is not able to compensate the SMN1 gene depletion [28] since it mostly generates non-functional SMN protein. The latter, essential for cell survival, is localized in the cytoplasm, the nucleus and nucleoli [32,33], where it regulates several cellular processes including the assembly of various ribonucleoproteins. However, the molecular mechanism by which suboptimal levels of SMN lead to SMA remains largely unknown [34], but its important roles in maintaining the function of motoneurons and muscles are certain. In fact, SMN protein depletion also alters the homeostasis and functioning of other tissues including the skeletal muscle, heart, autonomic and enteric nervous systems, as well as the lymphatic, bone and the reproductive systems [35].

In addition to gene depletion, glia cells contribute to motoneuron degeneration in SMA pathology where abnormal microglia increase and astrogliosis and inflammatory cytokines released from activated astrocytes have also been documented [36-38]. Despite the genetic causes of SMA being well known, the mechanisms underlying motor neuron death are still poorly understood. The low levels of SMN might lead to a selective activation of intracellular stress signaling pathways that play a central role in initiating neurodegeneration $[39,40]$.

Therefore, in ALS and SMA, inflammation is a common step which contributes to the progression of neurodegenerative diseases, leading to neuron and muscle death (Table 2). Here, the main pathways, which induce inflammation and consequently neuron death in ALS and SMA, have been analyzed based on data from recent literature and by discussing the involvement of the innate immune system and of specific cellular processes.

Table 2. Similarities between ALS and SMA.

\begin{tabular}{c}
\hline ALS and SMA Similarities \\
\hline Neuroinflammation \\
\hline Motor neuron death \\
\hline Common molecular pathways \\
\hline Loss of muscle mass and strenght \\
\hline Weakness, breathing difficulties \\
\hline Muscle atrophy
\end{tabular}

\subsection{Innate Immune System}

Neuroinflammation includes cellular and molecular processes which encompass the activation of microglia and astrocytes and the infiltration of peripheral immune cells. Thus, abnormal glial and astrocyte activation, as well as peripheral immune cell infiltration in the brain, is neurotoxic and seems to contribute to ALS and SMA pathology [41,42]. In fact, some studies report that an increase in microglia leads to inflammation in the spinal cord of SMA model mice, even if the main mechanism of its activation remains unknown [38].

In nervous tissue microglia represents the main innate immune cell involved in brain development, maturation and homeostasis. Microglia impairment leads to neurodegeneration, resulting in inflammation and thus contributing to neurodegenerative diseases $[43,44]$. Gene mutations, directly linked to the immune system response, have recently been reported in ALS and SMA patients [45-51]. These genes seem to be involved in the immune system dysfunctions which occur in spinal muscle atrophies and could play a role in the initial steps of disease pathogenesis leading to either excessive inflammation or immunodeficiency [52,53]. Gene mutations can induce uncorrect proteostasis, dysregulated RNA metabolism, impaired nucleocytoplasmic transport, mitochondrial dysfunction and altered axonal transport. In particular, mutations in SOD1, TARDBP, FUS and C9orf72 cause aggregate formation and consequent inflammatory responses in microglia and neuron 
death $[47,50,52]$. In motor neurons, aggregate accumulation can disrupt the transport of mitochondria to areas of metabolic need, resulting in damage to cells and the eliciting of a neuroinflammatory response leading to further neuronal damage [54]. These aggregates have been observed in sporadic ALS patients and usually contained a wild type (WT) transactive response DNA-binding protein of $43 \mathrm{kDa}$ (TDP-43, encoded by TARDBP). Nuclear TDP-43 can be phosphorylated, mislocalized and aggregated in the cytoplasm $[55,56]$ and can act by activating NF- $\mathrm{kB}$, the transcription factor which regulates proinflammatory substrate activation $[57,58]$. Moreover, dominant mutations in the RNA-binding protein Fused in Sarcoma (FUS) have been identified as co-activators of NF- $\mathrm{kB}$, and its expression in microglia and astrocytes leads to TNF upregulation and consequent motor neuron death $[59,60]$. Therefore, aberrant, mutant or misfolded proteins aggregate in the cytoplasm or nucleus of microglia, astrocytes and neurons, leading to cellular organellar damage and neuronal death. For instance, mSOD1 accumulation into astrocytes leads to reactive or activated astrocytes which lose their beneficial effect and take on a detrimental role with aberrant glutamate clearance, mitochondrial disfunctions and reactive microglia [61].

Gene mutations, in particular on FUS, also interact with SMN1, the main cause of SMA, providing evidence that SMA and ALS are linked at the molecular level (Table 2) [12]. In fact, $\mathrm{NFKB}$ upregulation has been reported in SMA model mice [62] and in SMN-depleted BV2 cells too [63]. This is a consequence of SMN gene deletion, which induces the activation of an E3 ubiquitin ligase (TRAF6) downstream of NFKB and c-Jun NH2-terminal kinase (JNK) signaling. An increased phosphorylation of JNK mediates the neurodegeneration observed in the SMA phenotype [40] which involves caspase 3 activation and apoptotic neuron death [39]. JNK activation regulates various downstream targets which include neuronal development, regeneration and death $[39,40,64]$. In particular, when JNK phosphorylates c-Jun at serine 63 or 73 , it induces the formation of the AP- 1 complex and the activation of the c-Jun target gene, responsible for neuronal apoptosis both during physiological and pathological conditions. To date, the role of this pathway appears controversial. Pilato and coworkers [65] demonstrated no evidence of stress-activated JNK-c-Jun signaling in SMA mice or human tissues (thoracic spinal cord samples of SMA patients had been collected during autopsies), while also recognizing its fundamental contribution to normal motoneuron development. Moreover, $\mathrm{TNF} \alpha$, the major proinflammatory cytokine, acting through two main receptors, the p55 TNF $\alpha$ receptor (TNFR1) and the p75 TNF $\alpha$ receptor (TNFR2), is implicated in motor neuron death. TNFR2 expressed by astrocytes and neurons is implicated in motor neuron loss in primary astrocyte-spinal neuron co-cultures [66]. Its upregulation contributes to motor neuron degeneration in SMA pathology by inducing uncontrolled neuronal apoptosis due to the partial loss (about 50\%) of NAIP gene (neuronal apoptosis inhibitory protein), as demonstrated in SMA type I patients [67].

Thus, NFKB appears the main inflammatory factor, common both in SMA and ALS phenotypes, where it mediates the inflammatory response in microglia. Microglia appears massively activated in the regions of neural loss, determining a condition known as "reactive microgliosis", and interacting with inflammatory T lymphocytes as well as astrocytes in order to provide inflammatory response [68,69]. Microglia activation in the central nervous system (CNS) is heterogeneous and can develop two phenotypes, known as M1, which promotes the neurodegeneration in atrophic diseases [70], and M2, with a neuroprotective effect (Table 3). The M1 microglia phenotype contributes to NF- $\mathrm{kB}$ upregulation mediating the activation of pro-inflammatory cytokines, e.g., IL-6, IL-1 $\beta$ and TNF $\alpha$, and to the pro-inflammatory enzymes which induce an increase in the levels of reactive oxygen species (ROS) and, consequently, neuron death [71-74].

Astrocytes, on the other hand, are the most abundant glial cells in the CNS, where they modulate ionic homeostasis, the action of neurotransmitters (particularly excitatory ones) and play a crucial role in secreting growth factors and nutrients to help neuronal survival $[75,76]$. Furthermore, they contribute to regulate blood-brain barrier function, synaptic plasticity and neuroprotection $[77,78]$. As described for microglia, reactive astrocytes also have two phenotypes, A1 and A2. The first phenotype expresses inflammatory 
cytokines which are harmful and destructive to synapses, whereas the second one produces neurotrophic factors and help synapse repair [79]. An excessive or disproportionate innate immune response promotes neuronal damage and chronic neuroinflammation, in particular that which is detected in the early stages of ALS and SMA $[69,80,81]$. Motor neuron degeneration is strictly related to the abnormality of the immune peripherical system with dysfunctions in T lymphocytes, monocytes and the complement system. There is some evidence which shows how genetic removal of $\mathrm{T}$ lymphocyte cells accelerated disease progression with the upregulation of proinflammatory cytokines in mSOD1 mice, while reconstitution of $\mathrm{T}$ lymphocyte cells seems to favor the survival of $\mathrm{mSOD} 1$ mice whilst inhibiting the activation of M1 microglia [82]. In SMA mouse models some alterations in $\mathrm{T}$ lymphocyte cell maturation or development have been reported and seem to result from an abnormal neuroinflammatory response and the exacerbation of disease [37]. Motor neuron loss is also mediated by monocyte activation which is characterized by a reduced phagocytosis and other dysfunctionalities. These cells have been found both in the blood and in the spinal cord of ALS patients [83]. Finally, even if the role of the complement pathway in ALS pathogenesis is still controversial, the complement system activation may precede end-plate denervation in human ALS [82]. Moreover, the complement system seems to play a central role in SMA disease, where its deregulation leads to the disruption of neuronal networks with consequent synaptic elimination by aberrant activated glia cells and compromised neuronal function. The classical complement pathway mediates the microglia-dependent remodeling of the spinal motor circuits during development and in SMA [84].

Table 3. Factors regulating M1/M2 microglia switching. Pro-inflammatory (Il-17, IFN $\gamma, \mathrm{TNF}-\alpha$ ) and anti-inflammatory (IL-4, IL-10, TGF- $\beta$ ) stimuli.

\begin{tabular}{cc}
\hline M1 & M2 \\
Neuroinflammation Induction & Homeostasis Mainteinance \\
\hline IL-17 & IL-4 \\
\hline IFN $\gamma$ & IL-10 \\
\hline TNF- $\alpha$ & TGF- $\beta$ \\
\hline Inflammatory cytochine production & anti-inflammatory molecule production \\
\hline
\end{tabular}

Therefore, under stress conditions, such as progressive neurodegeneration, both microglia and astrocytes appear activated, leading to detrimental outcomes in neuronal cell function due to the excess production of different neurotoxic cytokines and noxious molecules $[68,85]$. Figure 1 shows the main players of the innate immune system in the CNS, such as astrocytes and microglia, highlighting their morphology and localization. In addition, Figure 1C shows glia cell involvement in inducing neuron death. Thus, when glia cells are activated by genetic mutations or pro-inflammatory stimuli, they acquire a reactive phenotype and release pro-inflammatory components responsible for neuron degeneration. 

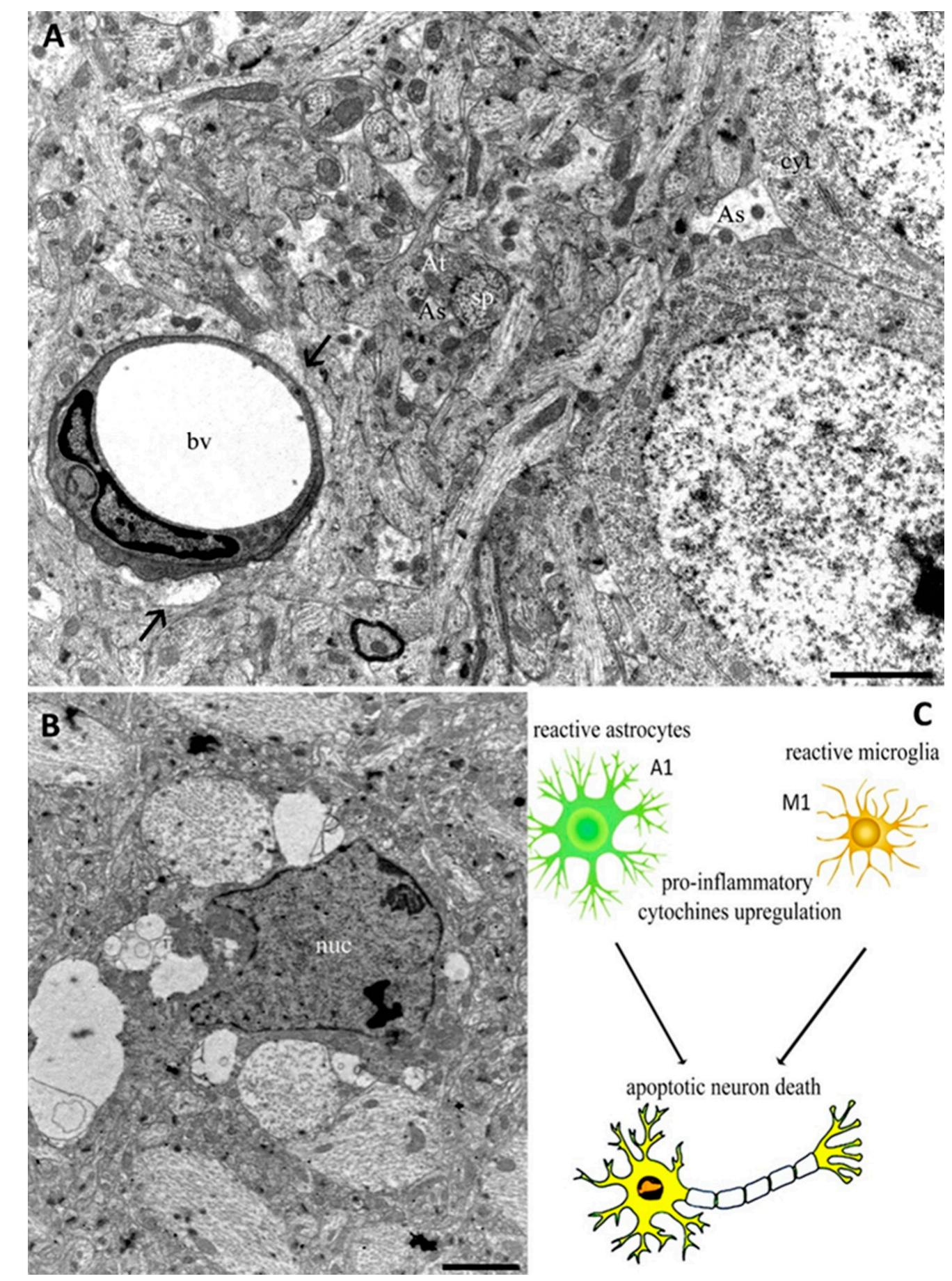

Figure 1. Transmission Electron Microscopy (TEM) images from cerebral cortex of adult rat (A,B). In (A), astrocyte end feet protrusions (arrows) can be observed near to a blood vessel (bv). Astrocyte processes (As) appear near axonal terminal (At) and dendritic spines (sp), as well as around neuron cytoplasm (cyt). The micrograph (B) shows a microglia cell characterized by a nucleus (nuc) with an irregular outline in which the chromatin is clumped beneath the nuclear envelope. The schematic representation of glia activation related to neuron death appears in (C). Bars $2 \mu \mathrm{m}$ for (A) and (B).

\subsection{Cellular Mechanisms}

Furthermore, cellular mechanisms, such as mitochondrial dysfunction, proteasomal and autophagic impairment, contribute to neuroinflammation and therefore to neuron degeneration [86-90]. In fact, other genes such as p62/SQSTM1, TBK1, OPTN, ALS2, CHMP2B, C9orf72 and CYLD appear activated in these diseases, where they enhance 
protein aggregation or misfolding with the impairment of proteasomal or autophagosome degradation and consequent inflammation [90-95]. In particular, mitochondria play a crucial role in the choice of neuron fate since they are the intracellular organelles mostly involved in the regulation of both cell survival and cell death [96-98]. Furthermore, some research revealed that this organelle plays a central role in modulating both innate and adaptive immune responses, thereby providing a link between neurodegenerative and neuroinflammatory processes $[89,99,100]$. In the CNS, energy production is essential for neuron communication. The large ATP amount is guaranteed from mitochondria which, in order to maintain a correct morphology and function, require the involvement of several processes such as: the synthesis of outer and inner mitochondrial membrane components and mitochondrial proteins, the synthesis and import of proteins encoded by the nuclear genome, lipid import, oxidative phosphorylation, the replication of mtDNA and mitochondrial fusion and fission $[98,100,101]$. In order to maintain mitochondrial biogenesis, the nuclear genome and the mitochondrial genome must work in a coordinated manner [101] to eliminate the risk of mitochondrial dysfunction and an increase in oxidative stress [102]. Furthermore, fusion and fission events are involved in regulating and controlling mitochondrial dynamics [103]. In fact, during fission process, defective mitochondria are removed by mitophagy [104], while healthy mitochondria selection is based on the number of mtDNA copies, optimum matrix metabolites, and components of the mitochondrial membrane $[103,105]$. Therefore, alterations in the processes which control mitochondrial biogenesis underlie neurodegeneration, resulting in neurodegenerative diseases, including ALS and SMA [106-108]. Mitochondrial complex deficiencies lead to protein hyperphosphorylation, such as the mutant SOD1, and proteosome activity impairment [98]. Alterations in mitochondrial morphology and dynamics observed in the pathogenesis of ALS seem due to high levels of free radicals and oxidative stress, as well as to the modification of the amount of proteins involved in mitochondrial fusion and fission. These abnormal processes induce both caspase-dependent and -independent apoptotic cell death directed by mitochondria, where the mutant SOD1, considered one of most common causes of ALS, plays a central role by interacting with the Bcl-2 protein family [109]. In particular, it has been observed that SOD1 mutations induce mitochondrial respiratory deficiencies $[110,111]$. In fact, in normal conditions this gene works as an antioxidant enzyme protecting neurons from the free superoxide radical. Therefore, its mutated form stimulates protein aggregation and apoptosis. Furthermore, mutant SOD1 mediates the alteration of the mitochondrial calcium-loading capacity, the impairment of electron transport chain activities, the increase in aberrant ROS production [112,113]. In addition, it blocks protein import at the mitochondrial outer membrane and the antiapoptotic actions of the Bcl-2 protein [98].

In SMA pathology, mitochondrial dysfunction, oxidative stress and the impairment of bioenergetic pathways could be correlated to SMN deficiency. High free radical levels have been observed in an SMA cell line and and in several SMA models, where dysfunctional mitochondria, an increase in cytochrome c oxidase activity, the potential loss of the mitochondrial membrane and altered axonal mitochondrial transport have been detected $[114,115]$.

Mitochondrial alterations, which affect microglia, astrocytes and neuron cells, are especially detrimental for neuron survival due to a low neuronal regeneration capacity. Therefore, mitochondrial dysfunctions play a central role in the pathogenesis of neurological disorders. Figure 2 shows mitochondrial morphology in a homoeostatic condition, where the subcellular organelles, localized into astrocytes, dendritic cells and axon terminals, present a preserved cristae rearrangement and, sometimes, fusion mitochondria morphology can be observed, suggesting a cellular function preservation. 


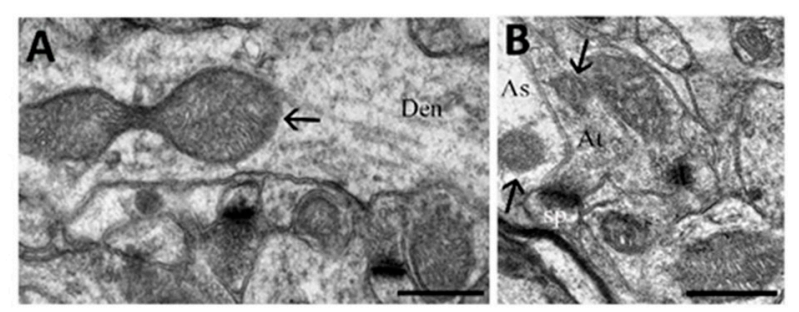

MITOCHONDRIAL HOMEOSTASIS

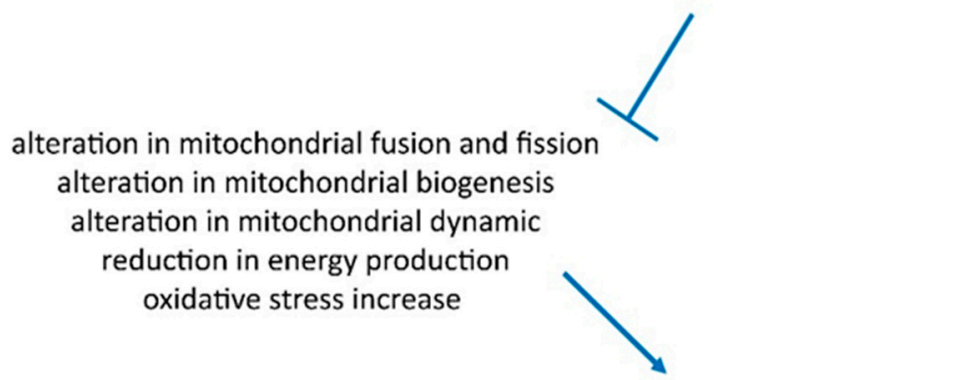

DYSFUNCTIONAL MITOCHONDRIA

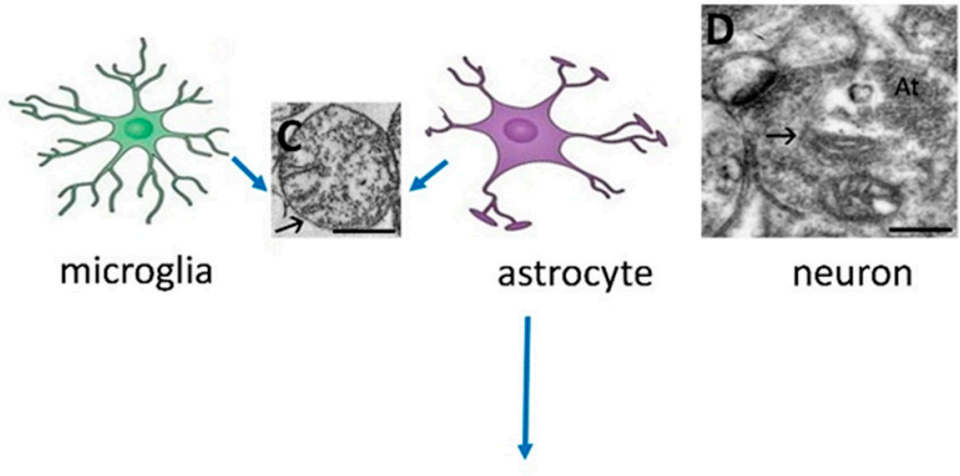

NEURON INFLAMMATION AND DEATH

Figure 2. The scheme suggests that preserved mitochondrial processes such as correct biogenesis, fission and fusion, dynamics and other processes are necessary to reach neuron homeostasis. On the other hand, their deregulation in glial cells or neurons contributes to neuroninflammation and death. TEM images, obtained from an adult rat's cerebral cortex, show mitochondria (arrows) in a dendritic cell (Den) during a fusion event (A), in an axon terminal (At) and in an astrocyte process (As) which surrounds a synapse (B). Altered mitochondria (black arrows) appear in (C,D). Bars: $500 \mathrm{~nm}$ for (A-C); $200 \mathrm{~nm}$ for (D). sp: dendritic spine.

Alterations in mitochondrial morphology and dynamics lead to important implications for cellular function. In particular, dysfunctional mitochondria on resident cells, such as microglia and astrocytes, reduce their role in supporting neuronal survival, synaptic functions and local immunity, thus promoting inflammation and cell death [116].

SMA pathology is primarily characterized by apoptotic motor neuron death in the spinal cord, mediated, at least in part, by mitochondria [117,118]. These organelles activate the intrinsic pathway of apoptosis [119], which involve a combination of pro- and antiapoptotic proteins, including Bcl-2 family members, caspase family members, cytochrome $\mathrm{c}$ and p53. Several studies have shown altered levels of these proteins in patients and models of SMA [120]. Moreover, the NAIP gene, located within the genomic region of chromosome 5 that encompasses SMN1, plays a crucial role in neuron fate. In fact, mutations of NAIP, a gene previously described in the activation of the immune system, induce and increase in the release of caspases 3 and 9 during apoptosis, with deleterious consequences for SMA motor neurons and, thus, an acceleration in the progression of the pathology [118,121,122]. Different apoptotic pathways are responsible for motoneuron loss both in ALS and SMA. In the Drosophila S2 cell model, SMN loss activates the caspasedependent apoptotic signaling, with upregulation of Fas ligand-mediated apoptosis and 
of caspase 8 and 3 [123,124]. A critical regulator role in neuronal apoptosis has been associatedwith the Bcl-2 family proteins. In particular, in muscle atrophy diseases the Bcl-2 anti-apototic proteins, such as Bcl-2 and Bcl-X, appear downregulated by enhancing neuronal apoptosis [124-128]. Moreover, the nucleolus accumulation of $\mathrm{p}-53$, a protein which regulates neuronal apoptotic death and usually binds to the SMN protein (when it is not truncated), contributes to the activation of apoptosis in motor neuron. Finally, MAP kinase cascades, implicated in the modulation of proliferation, differentiation, apoptosis or survival, inflammation and innate immunity, also regulate neuron apoptosis. This pathway acts by activating mitogen-activated protein kinases (MAPKs) such as JNK, p38 MAPK and TNF- $\alpha$ pathways, and their upregulation contributes to the pathology of neuro-muscular disorders [63,69].

Therefore, maintaining mitochondria homeostasis in the CNS is a prerequisite to avoid the excessive generation of ROS and cell death and could represent the starting point for the treatment of inflammatory motor neuron diseases. The main mechanisms involved in achieving mitochondrial functional homeostasis, are the ubiquitin-proteasome system, which specifically targets unfolded proteins [6,129], and mitophagy, which controls the mitochondria's quality and can represent the possible therapeutic target for alleviating cell death and nervous tissue injury [130]. When misfolded aggregated proteins, which are one of the features of neurodegenerative disorders, accumulate in the cytoplasm, they activate the unfolded protein response (UPR) pathway. Among the stress sensors involved in UPR activation, an important key regulator is the protein kinase $\mathrm{R}$ (PKR). It is a member of a family of serine-threonine kinases that phosphorylate the translation initiation factor in its subunit $[131,132]$. This inhibits most cellular translation and selectively promotes the translation of cytoprotective genes that enhance the protein folding or degradation of misfolded proteins. When the UPR is overwhelmed by misfolded proteins and is unable to adequately protect the cell during times of stress, cellular apoptosis and autophagy are induced [133]. This particularly occurs in ALS, which is characterized by the abnormal accumulation of misfolded or aggregated proteins, and therefore the dysfunction of proteostasis which significantly increases endoplasmic reticulum stress and leads to neuronal degeneration $[134,135]$.

A key role in mitochondrial homeostasis is played by mitophagy, which can be initiated via PINK1 (PTEN induced putative kinase 1) and PRKN (parkin RBR E3 ubiquitin protein ligase) -dependent and -independent pathways, through which damaged mitochondria are selectively degraded by lysosomes [136]. In particular, altered mitochondria are not able to import PINK1 into the inner mitochondrial membrane, leading to the accumulation of PINK1 on the outer mitochondrial membrane which cause the activation of ubiquitin or PRKN, linking phosphoubiquitin chains to various mitochondrial surface-associated proteins. The latter are recognized by cargo-receptor proteins such as SQSTM1/p62 (sequestosome 1), OPTN (optineurin) and NBR1 (NBR1 autophagy cargo receptor) that subsequently interact with MAP1LC3B/LC3B (microtubule associated protein 1 light chain 3 beta) to start autophagosome formation [137]. Intriguingly, these receptors can be the target of activated TBK1 (TANK binding kinase 1), which enhances mitophagy by phosphorylating autophagic receptors, especially OPTN [138-140]. Several authors have been demonstrated that the loss of function of OPTN or TBK1 or mutations in some genes such as SQSTM1 result in impaired mitophagy which leads to the accumulation of damaged mitochondria. This impairment, characterized by the inefficient turnover of mitochondria, has been identified in different ALS models. Thus, mitochondrial dysfunction and accumulation can be considered a prevalent feature in the motor neuron degeneration of ALS patients [137,139,141].

Furthermore, TDP-43 seems involved in the alteration of several mitochondrial pathways such as mitochondrial dynamics, mitochondrial trafficking and energetic metabolism [142]. In fact, ALS patients show high amounts of TDP-43 aggregates in mitochondria, which induce mitochondrial damage and cell death. On the other hand, blocking the link between TDP-43 and mitochondria is sufficient to prevent the neuronal 
loss and mitochondrial dysfunction $[143,144]$. Therefore, mutations in several genes known to contribute to ALS result in the deposition of their protein products as aggregates, by altering the correct mitophagy, resulting in damage to cells, and thus eliciting a neuroinflammatory response leading to further neuronal damage and death. As described above, impaired mitochondrial biogenesis has been reported in the muscle of SMA patients as well as in the motor neurons of SMA mice too $[87,145]$. In particular, in SMNdeficient spinal motoneurons, a dysregulation in mitochondrial bioenergetics-related genes, a reduction of ATP synthesis and oxidative stress increase have been described by several authors $[87,146,147]$. Furthermore, an impairment of the autophagic degradative pathway has been observed in cell culture and animal models of SMA too. In vitro studies in SMN-depleted cells demonstrated increased p62/SQSTM1 protein levels suggesting a decreased autophagic flux $[148,149]$. On the other hand, Piras et al. demonstrated that the inhibition of autophagy suppressed autophagosome formation and reduced the apoptotic activation [150]. Therefore, to date, the role of autophagy/mitophagy in SMA disease remains controversial and should be further investigated.

\section{Conclusions}

Neuro-muscular disorders are diseases that affect the development and growth of the neuro-muscular system $[4,151,152]$. The pathology can appear anywhere along the neuro-muscular pathway; in the brain, the nerves and muscle fibers [152]. Although there is a recognized multitude of neuro-muscular disorders, this review describes the role of inflammation in motor neuron disorders by highlighting the involvement of the main pathways which lead to neuron death. ALS and SMA are a gene group of acquired or inherited rare disorders caused by injury or dysfunction of the anterior horn cells of the spinal cord (lower motor neurons) with severe consequences to the peripheral nerves, neuromuscular junctions, or skeletal muscles leading to muscle weakness and wastage $[36,153]$. In mouse models of several neuromuscular diseases, apoptosis signaling, which greatly contributes to pathology, appears activated by brain injury, including neuro-inflammation, damaged mitochondria and altered degradative processes. These alterations induce neuron cytotoxicity and death, resulting in neurological dysfunctions. For instance, ALS pathogenesis seems to be caused by numerous interactions of molecular and genetic pathways. Several mutations are linked to ALS. To date, the main mutations have been detected in the SOD1, C9ORF72, TARDBP and FUS genes which lead to dysregulated RNA metabolism, with the formation of intracellular neuronal aggregates that have been detected in glia or neuron cell of ALS models. Mutations in the SOD1 gene increase oxidative stress by inducing mitochondrial dysfunction and defective axonal transport. Furthermore, impaired glutamate uptake from the synaptic cleft induces glutamate excitotoxicity due to the dysfunction of the glial excitatory amino acid transporters. All these factors trigger neurodegeneration and, among the mechanisms implicated in motor neuron disorder development, innate immune system alterations seem to play a crucial role in mediating neuronal damage $[154,155]$. It is known that glia cells play a crucial role for the immunity, neurogenesis, synaptogenesis, neurotrophic support and phagocytosis of cellular debris, as well as helping to maintain CNS integrity and homeostasis [155,156]. Activated microglia and astrocytes have the capacity to release proinflammatory mediators leading to neuroinflammation that, when they become uncontrolled, can give rise to various neurological disorders including ALS and SMA [155]. M1 microglia and A1 astrocyte uncontrolled activation leads to the inflammation and upregulation of inflammatory pathways. Both in ALS and SMA, the common inflammatory pathway requires the activation of NF- $\mathrm{kB}$, which induces the upregulation of downstream cytochines leading to apoptotic cascades and neuron death. Moreover, a crucial role in disease progression and development is related to mitochondrial alterations and autophagic impairment [87,99,157-159], which create aggregates of abnormal proteins with potential toxicities and cause inflammation response generation and finally apoptotic cell death (Scheme 1). As a consequence, due to the inability to get rid of the irregular aggregate proteins, neurons are unable to properly function 
and begin to degenerate. Therefore, the process of modulating neuro-inflammation and maintaining a correct mitochondrial function and morphology could represent an effective therapeutic target for ALS and SMA treatment.

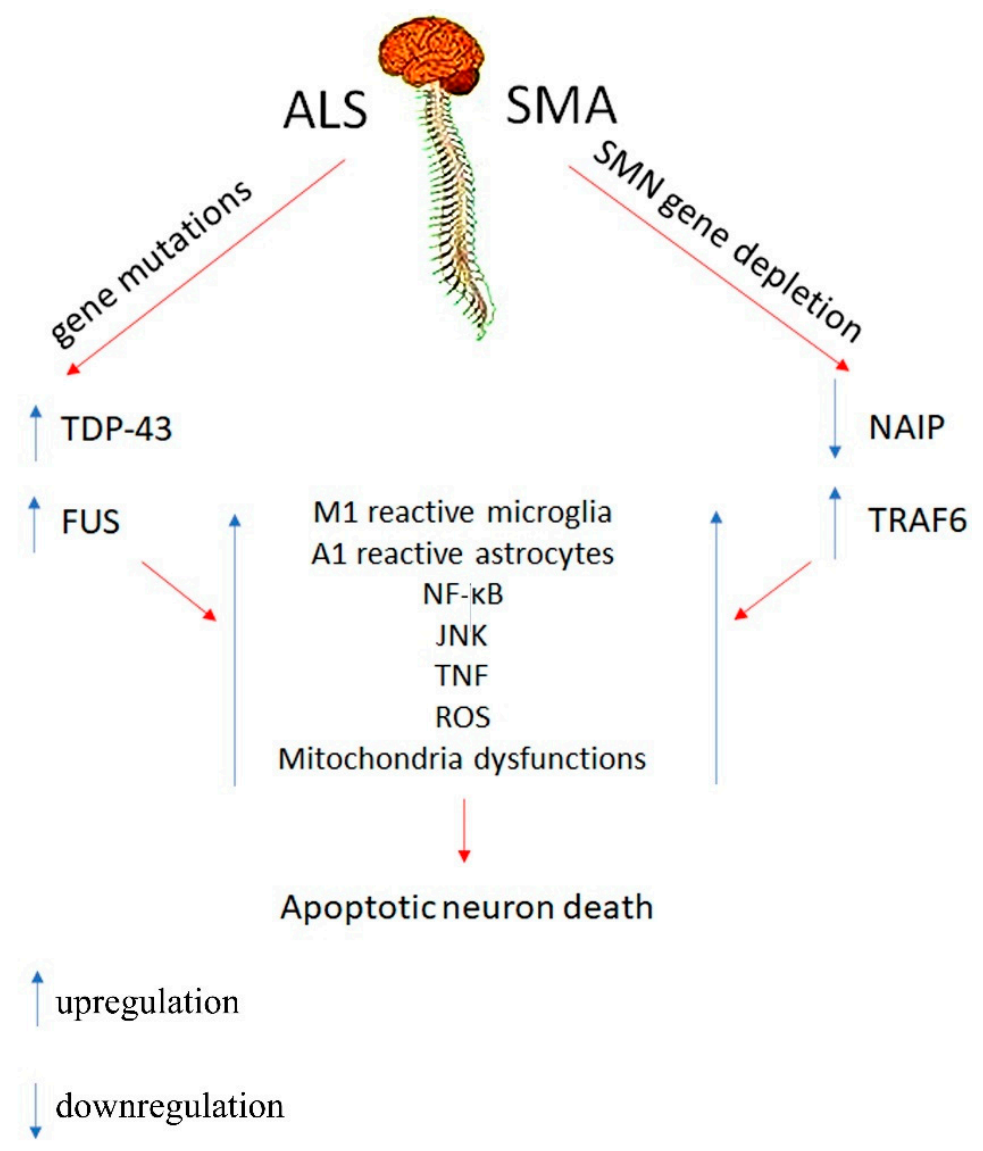

Scheme 1. The scheme shows the main cellular factors which contribute to neuroinflammation and lead to apoptotic neuron death in SMA and ALS diseases.

Author Contributions: Investigation, A.S.B.; methodology, S.S. and P.G.; supervision, L.I.C., P.G. and I.F.; visualization, M.B., S.B. and A.B.; writing—original draft: S.S.; writing-review and editing, S.S., P.G. and I.F. The contribution of P.G. and I.F. to this study work is the same and should be regarded as co-last authors. All authors have read and agreed to the published version of the manuscript.

Funding: This research received no external funding.

Acknowledgments: We wish to thank Elisabetta Falcieri for her scientific support in the supervision of the manuscript.

Conflicts of Interest: The authors declare no conflict of interest.

\section{References}

1. Meacci, E.; Garcia-Gil, M. S1P/S1P Receptor Signaling in Neuromuscolar Disorders. Int. J. Mol. Sci. 2019, 20, 6364. [CrossRef]

2. Cowling, B.S.; Thielemans, L. Translational medicine in neuromuscular disorders: From academia to industry. Dis. Model. Mech. 2019, 13, 41434. [CrossRef]

3. Dowling, J.J.; D. Gonorazky, H.; Cohn, R.D.; Campbell, C. Treating pediatric neuromuscular disorders: The future is now. Am. J. Med. Genet. 2018, 176, 804-841. [CrossRef] [PubMed]

4. Bhatt, J.M. The Epidemiology of Neuromuscular Diseases. Neurol. Clin. 2016, 34, 999-1021. [CrossRef] [PubMed]

5. Morrison, B.M. Neuromuscular Diseases. Semin. Neurol. 2016, 36, 409-418. [CrossRef] [PubMed]

6. Salucci, S.; Falcieri, E. Polyphenols and their potential role in preventing skeletal muscle atrophy. Nutr. Res. 2020, 74, 10-22. [CrossRef] [PubMed] 
7. Grande, V.; Hathazi, D.; O'Connor, E.; Marteau, T.; Schara-Schmidt, U.; Hentschel, A.; Genevieve, G.; Nikolenko, N.; Lochmüller, H.; Roos, A. Dysregulation of GSK3 $\beta$-Target Proteins in Skin Fibroblasts of Myotonic Dystrophy Type 1 (DM1) Patients. J. Neuromuscul. Dis. 2021. [CrossRef]

8. Azotla-Vilchis, C.N.; Sanchez-Celis, D.; Agonizantes-Juárez, L.E.; Suárez-Sánchez, R.; Hernández-Hernández, J.M.; Peña, J.; Vázquez-Santillán, K.; Leyva-García, N.; Ortega, A.; Maldonado, V.; et al. Transcriptome Analysis Reveals Altered Inflammatory Pathway in an Inducible Glial Cell Model of Myotonic Dystrophy Type 1. Biomolecules 2021, 11, 159. [CrossRef] [PubMed]

9. Müller, L.; Di Benedetto, S.; Pawelec, G. The Immune System and Its Dysregulation with Aging. Rev. Subcell. Biochem. 2019, 91, 21-43.

10. Comley, L.H.; Nijssen, J.; Frost-Nylen, J.; Hedlund, E. Cross-disease comparison of amyotrophic lateral sclerosis and spinal muscular atrophy reveals conservation of selective vulnerability but differential neuromuscular junction pathology. J. Comp. Neurol. 2016, 524, 1424-1442. [CrossRef]

11. Perez-Garcia, M.J.; Kong, L.; Sumner, C.J.; Tizzano, E.F. Spinal Muscular Atrophy: Disease Mechanisms and Therapy; Sumner, C.J., Paushkin, S., Ko, C.P., Eds.; Elsevier: London, UK, 2017; pp. 21-40.

12. Chi, B.; O'Connell, J.D.; Iocolano, A.D.; Coady, J.A.; Yu, Y.; Gangopadhyay, J.; Gygi, S.P.; Reed, R. The neurodegenerative diseases ALS and SMA are linked at the molecular level via the ASC-1 complex. Nucleic Acids Res. 2018, 46, 11939-11951. [CrossRef] [PubMed]

13. Šoltić, D.; Bowerman, M.; Stock, J.; Shorrock, H.K.; Gillingwater, T.H.; Fuller, H.R. Multi-Study Proteomic and Bioinformatic Identification of Molecular Overlap between Amyotrophic Lateral Sclerosis (ALS) and Spinal Muscular Atrophy (SMA). Brain Sci. 2018, 8, 212. [CrossRef]

14. Hensel, N.; Claus, P. The Actin Cytoskeleton in SMA and ALS: How Does It Contribute to Motoneuron Degeneration? Neuroscientist 2018, 24, 54-72. [CrossRef]

15. Bonafede, R.; Mariotti, R. ALS Pathogenesis and Therapeutic Approaches: The Role of Mesenchymal Stem Cells and Extracellular Vesicles. Front. Cell. Neurosci. 2017, 11, 80. [CrossRef]

16. Renton, A.E.; Chio, A.; Traynor, B.J. State of play in amyotrophic lateral sclerosis genetics. Nat. Neurosci. 2014, 17, 17-23. [CrossRef] [PubMed]

17. Al-Chalabi, A.; Calvo, A.; Chio, A.; Colville, S.; Ellis, C.M.; Hardiman, O.; Heverin, M.; Howard, R.S.; Huisman, M.H.B.; Keren, N.; et al. Analysis of amyotrophic lateral sclerosis as a multistep process: A population-based modelling study. Lancet Neurol. 2014, 13, 1108-1113. [CrossRef]

18. Droppelmann, C.A.; Campos-Melo, D.; Ishtiaq, M.; Volkening, K.; Strong, M.J. RNA metabolism in ALS: When normal processes become pathological. Amyotroph. Lateral Scler. Front. Degener. 2014, 15, 321-326. [CrossRef]

19. Serio, A.; Patani, R. Concise review: The cellular conspiracy of amyotrophic lateral sclerosis. Stem Cells 2018, 36, 293-303. [CrossRef]

20. Faenza, I.; Blalock, W.; Bavelloni, A.; Schoser, B.; Fiume, R.; Pacella, S.; Piazzi, M.; D’Angelo, A.; Cocco, L. A role for PLC $\beta 1$ in myotonic dystrophies type 1 and 2. FASEB J. 2012, 26, 3042-3048. [CrossRef]

21. Staats, K.A.; Van Helleputte, L.; Jones, A.R.; Bento-Abreu, A.; Van Hoecke, A.; Shatunov, A.; Simpson, C.L.; Lemmens, R.; Jaspers, T.; Fukami, K.; et al. Genetic ablation of phospholipase C delta 1 increases survival in SOD1(G93A) mice. Neurobiol. Dis. 2013, 60, 11-17. [CrossRef] [PubMed]

22. Kumar, D.R.; Aslinia, F.; Yale, S.H.; Mazza, J.J. Jean-Martin Charcot: The father of neurology. Clin. Med. Res. 2011, 9, 46-49. [CrossRef] [PubMed]

23. Mishra, P.S.; Dhull, D.K.; Nalini, A.; Vijayalakshmi, K.; Sathyaprabha, T.N.; Alladi, P.A.; Raju, T.R. Astroglia acquires a toxic neuroinflammatory role in response to the cerebrospinal fluid from amyotrophic lateral sclerosis patients. J. Neuroinflamm. 2016, 13, 212. [CrossRef] [PubMed]

24. Hardiman, O.; Al-Chalabi, A.; Chio, A.; Corr, E.M.; Logroscino, G.; Robberecht, W.; Shaw, P.J.; Simmons, Z.; van den Berg, L.H. Amyotrophic Lateral Sclerosis; CRC Press: Boca Raton, FL, USA, 2017; Volume 5, p. 17071.

25. Mejzini, R.; Flynn, L.L.; Pitout, I.L.; Fletcher, S.; Wilton, S.D.; Akkari, P.A. ALS genetics, mechanisms, and therapeutics:Where are we now? Front. Neurosci. 2019, 13, 1310. [CrossRef]

26. Pang, W.; Hu, F. Cellular and physiological functions of C9ORF72 and implications for ALS/FTD. J. Neurochem. 2021, 157, 334-350. [CrossRef]

27. Herrando-Grabulosa, M.; Gaja-Capdevila, N.; Vela, J.M.; Navarro, X. Sigma 1 receptor as a therapeutic target for amyotrophic lateral sclerosis. Br. J. Pharmacol. 2021, 178, 1336-1352. [CrossRef]

28. Darras, B.T.; Farrar, M.A.; Mercuri, E.; Finkel, R.S.; Foster, R.; Hughes, S.G.; Bhan, I.; Farwell, W.; Gheuens, S. An Integrated Safety Analysis of Infants and Children with Symptomatic Spinal Muscular Atrophy (SMA) Treated with Nusinersen in Seven Clinical Trials. CNS Drugs 2019, 33, 919-932. [CrossRef]

29. Donlin-Asp, P.G.; Fallini, C.; Campos, J.; Chou, C.C.; Merritt, M.E.; Phan, H.C.; Bassell, G.J.; Rossoll, W. The survival of motor neuron protein acts as a molecular chaperone for mRNP assembly. Cell Rep. 2017, 18, 1660-1673. [CrossRef] [PubMed]

30. Al-Zaidy, S.A.; Mendell, J.R. From Clinical Trials to Clinical Practice: Practical Considerations for Gene Replacement Therapy in SMA Type 1. Pediatric Neurol. 2019, 100, 3-11. [CrossRef]

31. Ross, L.F.; Kwon, J.M. Spinal Muscular Atrophy: Past, Present, and Future. Neoreviews 2019, 20, e437-e451. [CrossRef] 
32. Tisdale, S.; Lotti, F.; Saieva, L.; Van Meerbeke, J.P.; Crawford, T.O.; Sumner, C.J.; Mentis, G.Z.; Pellizzoni, L. SMN is essential for the biogenesis of U7 small nuclear ribonucleoprotein and 3'-end formation of histone mRNAs. Cell Rep. 2013, 5, $1187-1195$. [CrossRef] [PubMed]

33. So, B.R.; Wan, L.; Zhang, Z.; Li, P.; Babiash, E.; Duan, J.; Younis, I.; Dreyfuss, G. A U1 snRNP-specific assembly pathway reveals the SMN complex as a versatile hub for RNP exchange. Nat. Struct. Mol. Biol. 2016, 23, 225-230. [CrossRef]

34. Nash, L.A.; Burns, J.K.; Chardon, J.W.; Kothary, R.; Parks, R.J. Spinal Muscular Atrophy: More than a Disease of Motor Neurons? Curr. Mol. Med. 2016, 16, 779-792. [CrossRef]

35. Wan, B.; Feng, P.; Guan, Z.; Sheng, L.; Liu, Z.; Hua, Y. A severe mouse model of spinal muscular atrophy develops early systemic inflammation. Hum. Mol. Genet. 2018, 27, 4061-4076. [CrossRef] [PubMed]

36. Papadimitriou, D.; Le Verche, V.; Jacquier, A.; Ikiz, B.; Przedborski, S.; Re, D.B. Inflammation in ALS and SMA: Sorting out the good from the evil. Neurobiol. Dis. 2010, 37, 493-502. [CrossRef] [PubMed]

37. Deguise, M.O.; Kothary Deguise, M.O.; Kothary, R. New insights into SMA pathogenesis: Immune dysfunction and neuroinflammation. Ann. Clin. Transl. Neurol. 2017, 4, 522-530. [CrossRef] [PubMed]

38. Ando, S.; Osanai, D.; Takahashi, K.; Nakamura, S.; Shimazawa, M.; Hara, H. Survival motor neuron protein regulates oxidative stress and inflammatory response in microglia of the spinal cord in spinal muscular atrophy. J. Pharmacol. Sci. 2020, 144, 204-211. [CrossRef] [PubMed]

39. Schellino, R.; Boido, M.; Borsello, T.; Vercelli, A. Pharmacological c-Jun NH(2)-Terminal Kinase (JNK) Pathway Inhibition Reduces Severity of Spinal Muscular Atrophy Disease in Mice. Front. Mol. Neurosci. 2018, 11, 308. [CrossRef]

40. Genabai, N.K.; Ahmad, S.; Zhang, Z.; Jiang, X.; Gabaldon, C.A.; Gangwani, L. Genetic inhibition of JNK3 ameliorates spinal muscular atrophy. Hum. Mol. Genet. 2015, 24, 6986-7004. [CrossRef]

41. DiSabato, D.J.; Quan, N.; Godbout, J.P. Neuroinflammation: The devil is in the details. J. Neurochem. 2016, 139, 136-153. [CrossRef]

42. Ransohoff, R.M. How neuroinflammation contributes to neurodegeneration. Science 2016, 353, 777-783. [CrossRef] [PubMed]

43. Colonna, M.; Butovsky, O. Microglia Function in the Central Nervous System during Health and Neurodegeneration. Annu. Rev. Immunol. 2017, 35, 441-468. [CrossRef]

44. Cowan, M.; Petri, W.A., Jr. Microglia: Immune Regulators of Neurodevelopment. Front. Immunol. 2018, 9, 2576. [CrossRef]

45. Maruyama, H.; Morino, H.; Ito, H.; Izumi, Y.; Kato, H.; Watanabe, Y.; Kinoshita, Y.; Kamada, M.; Nodera, H.; Suzuki, H.; et al. Mutations of optineurin in amyotrophic lateral sclerosis. Nature 2010, 465, 223-226. [CrossRef] [PubMed]

46. Al-Chalabi, A.; Jones, A.; Troakes, C.; King, A.; Al-Sarraj, S.; van den Berg, L.H. The genetics and neuropathology of amyotrophic lateral sclerosis. Acta Neuropathol. 2012, 124, 339-352. [CrossRef] [PubMed]

47. Phani, S.; Berengere Re, D.; Przedborski, S. The Role of the Innate Immune System in ALS. Front Pharmacol. 2012, 3, 150. [CrossRef] [PubMed]

48. Freischmidt, A.; Wieland, T.; Richter, B.; Ruf, W.; Schaeffer, V.; Müller, K.; Marroquin, N.; Nordin, F.; Hübers, A.; Weydt, P.; et al. Haploinsufficiency of TBK1 causes familial ALS and fronto-temporal dementia. Nat. Neurosci. 2015, 18, 631-636. [CrossRef] [PubMed]

49. Singh, R.N.; Singh, N.N. Mechanism of Splicing Regulation of Spinal Muscular Atrophy Genes. Adv. Neurobiol. 2018, 20 , 31-61. [PubMed]

50. Dobson-Stone, C.; Hallupp, M.; Shahheydari, H.; Ragagnin, A.M.G.; Chatterton, Z.; Carew-Jones, F.; Shepherd, C.E.; Stefen, H.; Paric, E.; Fath, T.; et al. CYLD is a causative gene for frontotemporal dementia-Amyotrophic lateral sclerosis. Brain 2020, 143, 783-799. [CrossRef]

51. Keinath, M.C.; Prior, D.E.; Prior, T.W. Spinal Muscular Atrophy: Mutations, Testing, and Clinical Relevance. Appl. Clin. Genet. 2021, 14, 11-25. [CrossRef]

52. McCombe, P.A.; Henderson, R.D. The Role of Immune and Inflammatory Mechanisms in ALS. Curr. Mol. Med. 2011, 11, 246-254. [CrossRef]

53. Deguise, M.O.; De Repentigny, Y.; McFall, E.; Auclair, N.; Sad, S.; Kothary, R. Immune dysregulation may contribute to disease pathogenesis in spinal muscular atrophy mice. Hum. Mol. Genet. 2017, 26, 801-819. [CrossRef] [PubMed]

54. Oakes, J.A.; Davies, M.C.; Collins, M.O. TBK1: A new player in ALS linking autophagy and neuroinflammation. Mol. Brain. 2017, 10, 5. [CrossRef] [PubMed]

55. Weskamp, K.; Barmada, S.J. TDP43 and RNA instability in amyotrophic lateral sclerosis. Brain Res. 2018, 1693, 67-74. [CrossRef]

56. Gao, J.; Wang, L.; Huntley, M.L.; Perry, G.; Wang, X. Pathomechanisms of TDP-43 in neurodegeneration. J. Neurochem. 2018, 146, 7-20. [CrossRef]

57. Swarup, V.; Phaneuf, D.; Dupré, N.; Petri, S.; Strong, M.; Kriz, J.; Julien, J.P. Deregulation of TDP-43 in amyotrophic lateral sclerosis triggers nuclear factor $\mathrm{kB}-$ mediated pathogenic pathways. J. Exp. Med. 2011, 208, 2429-2447. [CrossRef]

58. Picher-Martel, V.; Dutta, K.; Phaneuf, D.; Sobue, G.; Julien, J.P. Ubiquilin-2 drives NF-кB activity and cytosolic TDP-43 aggregation in neuronal cells. Mol. Brain 2015, 8,71. [CrossRef]

59. Maruyama, H. Identification of a new causative gene of amyotrophic lateral sclerosis; optineurin. Rinsho Shinkeigaku 2012, 52, 1-5. [CrossRef]

60. Kia, A.; McAvoy, K.; Krishnamurthy, K.; Trotti, D.; Pasinelli, P. Astrocytes expressing ALS-linked mutant FUS induce motor neuron death through release of tumor necrosis factor-alpha. Glia 2018, 66, 1016-1033. [CrossRef]

61. Yamanaka, K.; Komine, O. The multi-dimensional roles of astrocytes in ALS. Neurosci. Res. 2018, 126, 31-38. [CrossRef] [PubMed] 
62. Ando, S.; Suzuki, S.; Okubo, S.; Ohuchi, K.; Takahashi, K.; Nakamura, S.; Shimazawa, M.; Fuji, K.; Hara, H. Discovery of a CNS penetrant small molecule SMN2 splicing modulator with improved tolerability for spinal muscular atrophy. Sci. Rep. 2020, 10, 17472. [CrossRef]

63. Kim, E.K.; Choi, E.J. SMN1 functions as a novel inhibitor for TRAF6-mediated NF-kB signaling. Biochim. Biophys. Acta Mol. Cell Res. 2017, 1864, 760-770. [CrossRef] [PubMed]

64. Coffey, E. TNuclear and cytosolic JNK signalling in neurons. Nat. Rev. Neurosci. 2014, 15, 285-299. [CrossRef]

65. Pilato, C.M.; Park, J.H.; Kong, L.; D’Ydewalle, C.; Valdivia, D.; Chen, K.S.; Griswold-Prenner, I.; Sumner, C.J. Motor neuron loss in SMA is not associated with somal stress-activated JNK/c-Jun signaling. Hum. Mol. Genet. 2019, 28, 3282-3292. [CrossRef] [PubMed]

66. Tortarolo, M.; Vallarola, A.; Lidonnici, D.; Battaglia, E.; Gensano, F.; Spaltro, G.; Fiordaliso, F.; Corbelli, A.; Garetto, S.; Martini, E.; et al. Lack of TNF-alpha receptor type 2 protects motor neurons in a cellular model of amyotrophic lateral sclerosis and in mutant SOD1 mice but does not affect disease progression. J. Neurochem. 2015, 135, 109-124. [CrossRef]

67. Götz, R. Regulation of neuronal cell death and differentiation by NGF and IAP family members. Adv. Res. Neurodegener. 2000, 60, 247-259.

68. Moisse, K.; Strong, M.J. Innate immunity in amyotrophic lateral sclerosis. Biochim. Biophys. Acta 2006, 1762, 1083-1093. [CrossRef]

69. Abati, E.; Citterio, G.; Bresolin, N.; Comi, G.P.; Corti, S. Glial cells involvement in spinal muscular atrophy: Could SMA be a neuroinflammatory disease? Neurobiol. Dis. 2020, 140, 104870. [CrossRef]

70. Cervero, C.; Blasco, A.; Tarabal, O.; Casanovas, A.; Piedrafita, L.; Navarro, X.; Esquerda, J.E.; Calderó, J. Glial activation and central synapse loss, but not motoneuron degeneration, are prevented by the sigma- 1 receptor agonist pre- 084 in the SMN2B/mouse model of spinal muscular atrophy. J. Neuropathol. Exp. Neurol. 2018, 77, 577-597. [CrossRef]

71. D'Ambrosi, N.; Rossi, S.; Gerbino, V.; Cozzolino, M. Rac1 at the crossroad of actin dynamics and neuroinflammation in Amyotrophic Lateral Sclerosis. Front. Cell Neurosci. 2014, 8, 279.

72. Grottelli, S.; Mezzasoma, L.; Scarpelli, P.; Cacciatore, I.; Cellini, B.; Bellezza, I. Cyclo(His-Pro) inhibits NLRP3 inflammasome cascade in ALS microglial cells. Mol. Cell Neurosci. 2019, 94, 23-31. [CrossRef]

73. de Araújo Boleti, A.P.; de Oliveira Flores, T.M.; Moreno, S.E.; Anjos, L.D.; Mortari, M.R.; Migliolo, L. Neuroinflammation: An overview of neurodegenerative and metabolic diseases and of biotechnological studies. Neurochem. Int. 2020, 136, 104714. [CrossRef]

74. Thelen, M.P.; Wirth, B.; Kye, M.J. Mitochondrial defects in the respiratory complex I contribute to impaired translational initiation via ROS and energy homeostasis in SMA motor neurons. Acta Neuropathol. Commun. 2020, 8, 223. [CrossRef]

75. Gobbi, P.; Castaldo, P.; Minelli, A.; Salucci, S.; Magi, S.; Corcione, E.; Amoroso, S. Mitochondrial localization of Na+/Ca2+ exchangers NCX1-3 in neurons and astrocytes of adult rat brain in situ. Pharmacol. Res. 2007, 56, 556-565. [CrossRef]

76. Salucci, S.; Ambrogini, P.; Lattanzi, D.; Betti, M.; Gobbi, P.; Galati, C.; Galli, F.; Cuppini, R.; Minelli, A. Maternal dietary loads of alpha-tocopherol increase synapse density and glial synaptic coverage in the hippocampus of adult offspring. Eur. J. Histochem. 2014, 58, 2355. [CrossRef]

77. Kacerovsky, J.B.; Murai, K.K. Stargazing: Monitoring subcellular dynamics of brain astrocytes. Neuroscience 2016, 323, 84-95. [CrossRef] [PubMed]

78. Li, K.; Li, J.; Zheng, J.; Qin, S. Reactive Astrocytes in Neurodegenerative Diseases. Aging Dis. 2019, 10, 664-675. [CrossRef] [PubMed]

79. Liddelow, S.A.; Barres, B.A. Reactive Astrocytes: Production, Function, and Therapeutic Potential. Immunity 2017, 46, 957-967. [CrossRef]

80. Sargsyan, S.A.; Monk, P.N.; Shaw, P.J. Microglia as potential contributors to motor neuron injury in amyotrophic lateral sclerosis. Glia 2005, 51, 241-253. [CrossRef] [PubMed]

81. Heneka MT, Kummer MP, Latz, E. Innate immune activation in neurodegenerative disease. Nat. Rev. Immunol. 2014, 14, 463-477. [CrossRef]

82. Liu, J.; Wang, F. Role of Neuroinflammation in Amyotrophic Lateral Sclerosis: Cellular Mechanisms and Therapeutic Implications. Front. Immunol. 2017, 8, 1005. [CrossRef]

83. Zondler, L.; Müller, K.; Khalaji, S.; Bliederhäuser, C.; Ruf, W.P.; Grozdanov, V.; Thiemann, M.; Fundel-Clemes, K.; Freischmidt, A.; Holzmann, K.; et al. Peripheral monocytes are functionally altered and invade the CNS in ALS patients. Acta Neuropathol. 2016, 132, 391-411. [CrossRef]

84. Vukojicic, A.; Delestrée, N.; Fletcher, E.V.; Pagiazitis, J.G.; Sankaranarayanan, S.; Yednock, T.A.; Barres, B.A.; Mentis, G.Z. The classical complement pathway mediates microglia-dependent remodeling of spinal motor circuits during development and in SMA. Cell Rep. 2019, 29, 3087-3100. [CrossRef]

85. Ghasemi, M.; Keyhanian, K.; Douthwright, C. Glial Cell Dysfunction in C9orf72-Related Amyotrophic Lateral Sclerosis and Frontotemporal Dementia. Cells 2021, 10, 249. [CrossRef] [PubMed]

86. Harland, M.; Torres, S.; Liu, J.; Wang, F. Neuronal Mitochondria Modulation of LPS-Induced Neuroinflammation. J Neurosci. 2020, 40, 1756-1765. [CrossRef] [PubMed]

87. Miller, N.; Shi, H.; Zelikovich, A.S.; Ma, Y.C. Motor neuron mitochondrial dysfunction in spinal muscular atrophy. Hum. Mol. Genet. 2016, 25, 3395-3406. [CrossRef] [PubMed] 
88. Obrador, E.; Salvador, R.; López-Blanch, R.; Jihad-Jebbar, A.; Vallés, S.L.; Estrela, J.M. Oxidative Stress, Neuroinflammation and Mitochondria in the Pathophysiology of Amyotrophic Lateral Sclerosis. Antioxidants 2020, 9, 901. [CrossRef] [PubMed]

89. Bader, V.; Winklhofer, K.F. Mitochondria at the interface between neurodegeneration and neuroinflammation. Semin. Cell Dev. Biol. 2020, 99, 163-171. [CrossRef] [PubMed]

90. Vicencio, E.; Beltrán, S.; Labrador, L.; Manque, P.; Nassif, M.; Woehlbier, U. Implications of Selective Autophagy Dysfunction for ALS Pathology. Cells 2020, 9, 381. [CrossRef] [PubMed]

91. Teyssou, E.; Takeda, T.; Lebon, V.; Boillée, S.; Doukouré, B.; Bataillon, G.; Sazdovitch, V.; Cazeneuve, C.; Meininger, V.; LeGuern, E.; et al. Mutations in SQSTM1 encoding p62 in amyotrophic lateral sclerosis: Genetics and neuropathology. Acta Neuropathol. 2013, 125, 511-522. [CrossRef]

92. Chantal Sellier, C.; Campanari, M.L.; Corbier, C.J.; Gaucherot, A.; Kolb-Cheynel, I.; Oulad-Abdelghani, M.; Ruffenach, F.; Page, A.; Ciura, S.; Kabashi, E.; et al. Loss of C9ORF72 impairs autophagy and synergizes with polyQ Ataxin-2 to induce motor neuron dysfunction and cell death. EMBO J. 2016, 35, 1276-1297. [CrossRef]

93. Corcia, P.; Couratier, P.; Blasco, H.; Andres, C.R.; Beltran, S.; Meininger, V.; Vourc'h, P. Genetics of amyotrophic lateral sclerosis. Rev. Neurol. 2017, 173, 254-262. [CrossRef]

94. Maurel, C.; Dangoumau, A.; Marouillat, S.; Brulard, C.; Chami, A.; Hergesheimer, R.; Corcia, P.; Blasco, H.; Andres, C.R.; Vourc'h, P. Causative Genes in Amyotrophic Lateral Sclerosis and Protein Degradation Pathways: A Link to Neurodegeneration. Mol. Neurobiol. 2018, 55, 6480-6499. [CrossRef]

95. Rodriguez-Muela, N.; Parkhitko, A.; Grass, T.; Gibbs, R.M.; Norabuena, E.M.; Perrimon, N.; Singh, R.; Rubin, L.L. Blocking p62-dependent SMN degradation ameliorates spinal muscular atrophy disease phenotypes. J. Clin. Investig. 2018, 128, 3008-3023. [CrossRef] [PubMed]

96. Salucci, S.; Baldassarri, V.; Canonico, B.; Burattini, S.; Battistelli, M.; Guescini, M.; Papa, S.; Stocchi, V.; Falcieri, E. Melatonin behavior in restoring chemical damaged C2C12 myoblasts. Microsc. Res. Tech. 2016, 79, 532-540. [CrossRef] [PubMed]

97. Salucci, S.; Battistelli, M.; Baldassarri, V.; Burini, D.; Falcieri, E.; Burattini, S. Melatonin prevents mitochondrial dysfunctions and death in differentiated skeletal muscle cells. Microsc. Res. Tech. 2017, 80, 1174-1181. [CrossRef] [PubMed]

98. Golpich, M.; Amini, E.; Mohamed, Z.; Azman Ali, R.; Mohamed Ibrahim, N.; Ahmadiani, A. Mitochondrial Dysfunction and Biogenesis in Neurodegenerative diseases: Pathogenesis and Treatment. CNS Neurosci. Ther. 2017, 23, 5-22. [CrossRef] [PubMed]

99. Joshi, A.U.; Minhas, P.S.; Liddelow, S.A.; Haileselassie, B.; Andreasson, K.I.; Dorn, G.W., 2nd; Mochly-Rosen, D. Fragmented mitochondria released from microglia trigger A1 astrocytic response and propagate inflammatory neurodegeneration. Nat. Neurosci. 2019, 22, 1635-1648. [CrossRef] [PubMed]

100. Garabadu, D.; Agrawal, N.; Sharma, A.; Sharma, S. Mitochondrial metabolism: A common link between neuroinflammation and neurodegeneration. Behav Pharmacol. 2019, 30, 642-652. [CrossRef]

101. Franco-Iborra, S.; Vila, M.; Perier, C. Mitochondrial quality control in neurodegenerative diseases: Focus on Parkinson's disease and Huntington's disease. Front. Neurosci. 2018, 12, 342. [CrossRef]

102. Pichaud, N.; Berube, R.; Cote, G.; Belzile, C.; Dufresne, F.; Morrow, G.; Tanguay, R.M.; Rand, D.M.; Blier, P.U. Age dependent dysfunction of mitochondrial and ROS metabolism induced by mitonuclear mismatch. Front. Genet. 2019, 10, 130. [CrossRef]

103. Valera-Alberni, M.; Canto, C. Mitochondrial stress management: A dynamic journey. Cell Stress 2018, 2, 253-274. [CrossRef]

104. Agarwal, S.; Yadav, A.; Tiwari, S.K.; Seth, B.; Chauhan, L.K.; Khare, P.; Ray, R.S.; Chaturvedi, R.K. Dynamin-related protein 1 inhibition mitigates bisphenol A-mediated alterations in mitochondrial dynamics and neural stem cell proliferation and differentiation. J. Biol. Chem. 2016, 291, 15923-15939. [CrossRef]

105. Youle, R.J.; van der Bliek, A.M. Mitochondrial fission, fusion, and stress. Science 2012, 337, 1062-1065. [CrossRef]

106. Uittenbogaard, M.; Chiaramello, A. Mitochondrial biogenesis: A therapeutic target for neurodevelopmental disorders and neurodegenerative diseases. Curr. Pharm. Des. 2014, 20, 5574-5593. [CrossRef] [PubMed]

107. Islam, M.T. Oxidative stress and mitochondrial dysfunction-linked neurodegenerative disorders. Neurol. Res. 2017, $39,73-82$. [CrossRef] [PubMed]

108. Goyal, S.; Chaturvedi, R.K. Mitochondrial Protein Import Dysfunction in Pathogenesis of Neurodegenerative Diseases. Mol. Neurobiol. 2021, 58, 1418-1437. [CrossRef]

109. Stanga, S.; Boido, M.; Kienlen-Campard, P. How to Build and to Protect the Neuromuscular Junction: The Role of the Glial Cell Line-Derived Neurotrophic Factor. Int. J. Mol. Sci. 2020, 22, 136. [CrossRef] [PubMed]

110. Menzies, F.M.; Ince, P.G.; Shaw, P.J. Mitochondrial involvement in amyotrophic lateral sclerosis. Neurochem. Int. 2002, 40, 543-551. [CrossRef]

111. Bahadorani, S.; Mukai, S.T.; Rabie, J.; Beckman, J.S.; Phillips, J.P.; Hilliker, A.J. Expression of zinc-deficient human superoxide dismutase in Drosophila neurons produces a locomotor defect linked to mitochondrial dysfunction. Neurobiol. Aging 2013, 34, 2322-2330. [CrossRef]

112. Tan, W.; Pasinelli, P.; Trotti, D. Role of mitochondria in mutant SOD1 linked amyotrophic lateral sclerosis. Biochim. Biophys. Acta. 2014, 1842, 1295-1301. [CrossRef]

113. Elfawy, H.A.; Das, B. Crosstalk between mitochondrial dysfunction, oxidative stress, and age related neurodegenerative disease: Etiologies and therapeutic strategies. Life Sci. 2019, 218, 165-184. [CrossRef] [PubMed]

114. Lotti, F.; Imlach, W.L.; Saieva, L.; Beck, E.S.; Hao, L.T.; Li, D.K.; Jiao, W.; Mentis, G.Z.; Beattie, C.E.; McCabe, B.D.; et al. An SMN-dependent U12 splicing event essential for motor circuit function. Cell 2012, 151, 440-454. [CrossRef] 
115. Boido, M.; Vercelli, A. Neuromuscular junctions as key contributors and therapeutic targets in spinal muscular atrophy. Front. Neuroanat. 2016, 10, 6. [CrossRef] [PubMed]

116. de Oliveira, L.G.; Angelo, Y.S.; Iglesias, A.H.; Peron, J.P.S. Unraveling the Link Between Mitochondrial Dynamics and Neuroinflammation. Front. Immunol. 2021, 2, 624919. [CrossRef] [PubMed]

117. Hellbach, N.; Peterson, S.; Haehnke, D.; Shankar, A.; LaBarge, S.; Pivaroff, C.; Thomas, C.; McCarthy, K.; Ebeling, M.; Metzger, F.; et al. Impaired myogenic development, differentiation and function in hESC-derived SMA myoblasts and myotubes. PLoS ONE 2018, 13, e1006744. [CrossRef]

118. James, R.; Chaytow, H.; Ledahawsky, L.M.; Gillingwater, T.H. Revisiting the role of mitochondria in spinal muscular atrophy. Cell Mol. Life Sci. 2021, 78, 4785-4804. [CrossRef] [PubMed]

119. Anderton, R.S.; Meloni, B.P.; Mastaglia, F.L.; Boulos, S. Spinal muscular atrophy and the anti-apoptotic role of survival of motor neuron (SMN) protein. Mol. Neurobiol. 2013, 47, 821-832. [CrossRef]

120. Xiong, S.; Mu, T.; Wang, G.; Jiang, X. Mitochondria-mediated apoptosis in mammals. Protein Cell 2014, 5, 737-749. [CrossRef]

121. Watihayati, M.S.; Fatemeh, H.; Marini, M.; Atif, A.B.; Zahiruddin, W.M.; Teguh Haryo Sasongko, T.H.; Tang, T.H.; Zabidi-Hussin, Z.A.; Nishio, H.; Zilfalil, B.A. Combination of SMN2 copy number and NAIP deletion predicts disease severity in spinal muscular atrophy. Brain Dev. 2009, 31, 42-45. [CrossRef]

122. Kofoed, E.M.; Vance, R.E. NAIPs: Building an innate immune barrier against bacterial pathogens: NAIPs function as sensors that initiate innate immunity by detection of bacterial proteins in the host cell cytosol. BioEssays 2012, 34, 589-598. [CrossRef]

123. Sareen, D.; Ebert, A.D.; Heins, B.M.; McGivern, J.V.; Ornelas, L.; Svendsen, C.N. Inhibition of apoptosis blocks human motor neuron cell death in a stem cell model of spinal muscular atrophy. PLoS ONE 2012, 7, e39113. [CrossRef]

124. Maretina, M.A.; Zheleznyakova, G.Y.; Lanko, K.M.; Egorova, A.A.; Baranov, V.S.; Kiselev., A.V. Molecular Factors Involved in Spinal Muscular Atrophy Pathways as Possible Disease-modifying Candidates. Curr. Genomics 2018, 19, 339-355. [CrossRef] [PubMed]

125. Ito, Y.; Shibata, N.; Saito, K.; Kobayashi, M.; Osawa, M. New insights into the pathogenesis of spinal muscular atrophy. Brain Dev. 2011, 33, 321-331. [CrossRef]

126. Bonafede, R.; Brandi, J.; Manfredi, M.; Scambi, I.; Schiaffino, L.; Merigo, F.; Turano, E.; Bonetti, B.; Marengo, E.; Cecconi, D.; et al. The Anti-Apoptotic Effect of ASC-Exosomes in an In Vitro ALS Model and Their Proteomic Analysis. Cells 2019, 8, 1087. [CrossRef]

127. Huang, S.L.; Wu, L.S.; Lee, M.; Chang, C.W.; Cheng, W.C.; Fang, Y.S.; Chen, Y.R.; Cheng, P.L.; Shen, C.J. A robust TDP-43 knock-in mouse model of ALS. Acta Neuropathol. Commun. 2020, 8, 3. [CrossRef]

128. Guo, Z.; Wu, H.T.; Li, X.X.; Yu, Y.; Gu, R.Z.; Lan, R.; Qin, X.Y. Edaravone protects rat astrocytes from oxidative or neurotoxic inflammatory insults by restoring Akt/Bcl-2/Caspase-3 signaling axis. IBRO Rep. 2020, 8, 122-128. [CrossRef]

129. Giordano, F.M.; Burattini, S.; Buontempo, F.; Canonico, B.; Martelli, A.M.; Papa, S.; Sampaolesi, M.; Falcieri, E.; Salucci, S. Diet Modulation Restores Autophagic Flux in Damaged Skeletal Muscle Cells. J. Nutr. Health Aging 2019, 23, 739-745. [CrossRef]

130. Von Stockum, S.; Nardin, A.; Schrepfer, E.; Ziviani, E. Mitochondrial dynamics and mitophagy in parkinson's disease: A fly point of view. Neurobiol. Dis. 2016, 90, 58-67. [CrossRef] [PubMed]

131. Piazzi, M.; Bavelloni, A.; Faenza, I.; Blalock, W. Glycogen synthase kinase (GSK)-3 and the double-strand RNA-dependent kinase, PKR: When two kinases for the common good turn bad. Biochim. Biophys. Acta Mol. Cell Res. 2020, 1867, 118769. [CrossRef] [PubMed]

132. Zu, T.; Guo, S.; Bardhi, O.; Ryskamp, D.A.; Li, J.; Khoramian Tusi, S.; Engelbrecht, A.; Klippel, K.; Chakrabarty, P.; Nguyen, L.; et al. Metformin inhibits RAN translation through PKR pathway and mitigates disease in C9orf72 ALS/FTD mice. Proc. Natl. Acad. Sci. USA 2020, 117, 18591-18599. [CrossRef] [PubMed]

133. Ghadge, G.D.; Sonobe, Y.; Camarena, A.; Drigotas, C.; Rigo, F.; Ling, K.K.; Roos, R.P. Knockdown of GADD34 in neonatal mutant SOD1 mice ameliorates ALS. Neurobiol. Dis. 2020, 136, 104702. [CrossRef] [PubMed]

134. Maharjan, N.; Saxena, S. ER strikes again: Proteostasis Dysfunction in ALS. EMBO J. 2016, 35, 798-800. [CrossRef] [PubMed]

135. Rodríguez-Muela, N. Autophagy in motor neuron diseases. Prog. Mol. Biol. Transl. Sci. 2020, 172, 157-202. [PubMed]

136. Ryter, S.W.; Bhatia, D.; Choi, M.E. Autophagy: A lysosome-dependent process with implications in cellular redox homeostasis and human disease. Antioxid. Redox Signal. 2019, 30, 138-159. [CrossRef]

137. Lazarou, M.; Sliter, D.A.; Kane, L.A.; Sarraf, S.A.; Wang, C.; Burman, J.L.; Sideris, D.P.; Fogel, A.I.; Youle, R.J. The ubiquitin kinase PINK1 recruits autophagy receptors to induce mitophagy. Nature 2015, 524, 309-314. [CrossRef]

138. Richter, B.; Sliter, D.A.; Herhaus, L.; Stolz, A.; Wang, C.; Beli, P.; Zaffagnini, G.; Wild, P.; Martens, S.; Wagner, S.A.; et al. Phosphorylation of OPTN by TBK1 enhances its binding to Ub chains and promotes selective autophagy of damaged mitochondria. Proc. Natl. Acad. Sci. USA 2016, 113, 4039-4044. [CrossRef]

139. Moore, A.S.; Holzbaur, E.L. Dynamic recruitment and activation of ALS-associated TBK1 with its target optineurin are required for efficient mitophagy. Proc. Natl. Acad. Sci. USA 2016, 113, E3349-E3358. [CrossRef]

140. Yao, R.Q.; Ren, C.; Xia, Z.F.; Yao, Y.M. Organelle-specific autophagy in inflammatory diseases: A potential therapeutic target underlying the quality control of multiple organelles. Autophagy 2021, 17, 385-401. [CrossRef]

141. Evans, C.S.; Holzbaur, E.L.F. Autophagy and mitophagy in ALS. Neurobiol. Dis. 2019, 122, 35-40. [CrossRef]

142. Huang, C.; Yan, S.; Zhang, Z. Maintaining the Balance of TDP-43, Mitochondria, and Autophagy: A Promising Therapeutic Strategy for Neurodegenerative Diseases. Transl. Neurodegener. 2020, 9, 40. [CrossRef] [PubMed] 
143. Wang, W.; Arakawa, H.; Wang, L.; Okolo, O.; Siedlak, S.L.; Jiang, Y.; Gao, J.; Xie, F.; Petersen, R.B.; Wang, X. Motor-Coordinative and Cognitive Dysfunction Caused by Mutant TDP-43 Could Be Reversed by Inhibiting Its Mitochondrial Localization. Mol. Ther. 2017, 25, 127-139. [CrossRef] [PubMed]

144. Madruga, E.; Maestro, I.; Martínez, A. Mitophagy Modulation, a New Player in the Race against ALS. Int. J. Mol. Sci. 2021, 22, 740. [CrossRef] [PubMed]

145. Singh, N.N.; Hoffman, S.; Reddi, P.P.; Singh, R.N. Spinal muscular atrophy: Broad disease spectrum and sex-specific phenotypes. Biochim. Biophys. Acta Mol. Basis Dis. 2021, 1867, 166063. [CrossRef] [PubMed]

146. Acsadi, G.; Lee, I.; Li, X.; Khaidakov, M.; Pecinova, A.; Parker, G.C.; Hüttemann, M. Mitochondrial dysfunction in a neural cell model of spinal muscular atrophy. J. Neurosci. Res. 2009, 87, 2748-2756. [CrossRef] [PubMed]

147. Lopez-Manzaneda, M.; Franco-Espin, J.; Tejero, R.; Cano, R.; Tabares, L. Calcium is reduced in presynaptic mitochondria of motor nerve terminals during neurotransmission in SMA mice. Hum. Mol. Genet. 2021, 30, 629-643. [CrossRef]

148. Custer, S.K.; Androphy, E.J. Autophagy dysregulation in cell culture and animals models of spinal muscular atrophy. Mol. Cell Neurosci. 2014, 61, 133-140. [CrossRef]

149. Periyakaruppiah, A.; de la Fuente, S.; Arumugam, S.; Bahí, N.; Garcera, A.; Soler, R.M. Autophagy modulators regulate survival motor neuron protein stability in motoneurons. Exp. Neurol. 2016, 283, 287-297. [CrossRef]

150. Piras, A.; Schiaffino, L.; Boido, M.; Valsecchi, V.; Guglielmotto, M.; De Amicis, E.; Puyal, J.; Garcera, A.; Tamagno, E.; Soler, R.M.; et al. Inhibition of autophagy delays motoneuron degeneration and extends lifespan in a mouse model of spinal muscular atrophy. Cell Death Dis. 2017, 8, 3223. [CrossRef] [PubMed]

151. David, W.S.; Chad, D.A. Neuromuscular Disorders. Semin. Neurol. 2015, 35, 325.

152. Ferlini, A.; Goyenvalle, A.; Muntoni, F. RNA-targeted drugs for neuromuscular diseases. Science 2021, 371, 29-31. [CrossRef]

153. Corcia, P.; Vourc'h, P.; Blasco, H.; Couratier, P.; Dangoumau, A.; Bellance, R.; Desnuelle, C.; Viader, F.; Pautot, V.; Millecamps, S.; et al. Phenotypic and genotypic studies of ALS cases in ALS-SMA families. Amyotroph. Lateral Scler. Front. Degener. 2018, 19, 432-437. [CrossRef] [PubMed]

154. Béland, L.C.; Markovinovic, A.; Jakovac, H.; De Marchi, F.; Bilic, E.; Mazzini, L.; Kriz, J.; Munitic, I. Immunity in amyotrophic lateral sclerosis: Blurred lines between excessive inflammation and inefficient immune responses. Brain Commun. 2020, 2 , fcaa124. [CrossRef] [PubMed]

155. Ashford, B.A.; Boche, D.; Cooper-Knock, J.; Heath, P.R.; Simpson, J.E.; Highley, J.R. Review: Microglia in motor neuron disease. Neuropathol. Appl. Neurobiol. 2021, 47, 179-197. [CrossRef]

156. Bagheri, H.; Ghasemi, F.; Barreto, G.E.; Sathyapalan, T.; Jamialahmadi, T.; Sahebkar, A. The effects of statins on microglial cells to protect against neurodegenerative disorders: A mechanistic review. Biofactors 2020, 46, 309-325. [CrossRef]

157. Boczonadi, V.; King, M.S.; Smith, A.C.; Olahova, M.; Bansagi, B.; Roos, A.; Eyassu, F.; Borchers, C.; Ramesh, V.; Lochmüller, H.; et al. Mitochondrial oxodicarboxylate carrier deficiency is associated with mitochondrial DNA depletion and spinal muscular atrophy-like disease. Genet. Med. 2018, 20, 1224-1235. [CrossRef] [PubMed]

158. Ripolone, M.; Ronchi, D.; Violano, R.; Vallejo, D.; Fagiolari, G.; Barca, E.; Lucchini, V.; Colombo, I.; Villa, L.; Berardinelli, A.; et al. Impaired Muscle Mitochondrial Biogenesis and Myogenesis in Spinal Muscular Atrophy. JAMA Neurol. 2015, 72, 666-675. [CrossRef]

159. Cabral-Costa, J.V.; Kowaltowski, A.J. Neurological disorders and mitochondria. Mol. Asp. Med. 2020, 71, 100826. [CrossRef] [PubMed] 